\title{
Competences of University Teachers: Systematic Literature Review
}

\author{
Nikola Gumanová \\ Denisa Šukolová \\ Faculty of Education, Matej Bel University, \\ Ružová 13, Banská Bystrica, 974 11, \\ Slovakia
}

DOI: https://doi.org/10.36941/jesr-2022-0031

\begin{abstract}
The transformation of tertiary education faces challenges that go hand in hand with growing requirements on the competences of university teachers. Quality assessment of teachers when it comes to their competences and competence approaches in general is of key importance in this process. However, teachers' competence profiles are not unified even now, not to mention the absence of competence assessment criteria. The aim of the study is to offer a literature review on university teachers' competences, with consideration of research methods and tools used. Altogether, through the Scopus and Web of Science electronic databases we summarised 35 studies, 15 theoretical and 20 empirical. Our analysis shows that over the past 10 years studies have primarily focused on digital competences, with the majority of research projects being of quantitative nature using original questionnaires due to the absence of standardised measurement tools in the field.
\end{abstract}

Key words: competences, university teacher, competence profile

\section{Introduction}

In recent years, higher education institutions have been facing new challenges and demands resulting from changing trends in education due to the globalising society, knowledge society, and knowledgebased society (Yakubov et al., 2020). According to Abykanov et al. (2016), universities are responsible for the quality of education and university teachers are in this respect regarded as a kind of custodian of quality. Therefore, the profession of university teacher is complex, with the teacher developing not only competences of the actors in the process, but also his or her own. This is how teachers ensure their continuous professional development, an integral part of which includes personal development, as both are based on the principle of self-development and self-regulation skills.

Yakubov (2017) believes competences are defined through a parameter of an individual's social role, claiming professional competences represent a system of knowledge, skills, and abilities that form the basis of professional activity in the role of university teacher and scholar. Abykanova et al. (2016) also argues that competence must be understood as a complex of professional tasks in which university teachers are to apply acquired expert knowledge and pedagogical thinking and demonstrate personal qualities allowing them to approach problem solving professionally in expert, scientific, and practical activities. This comprehensive understanding of competences makes this 
notion a subject of pedagogical but also interdisciplinary studies. It is teachers' potential for integrating individual aspects of competences considered necessary for performing a certain professional activity that predicts their pedagogical and work success.

Competence models of university teachers have become the subject of professional interest over the last decade, yet expert opinion remains mostly inconsistent. Alqiawi and Ezzeldin (2015) emphasize that university teachers should have academic (professional) competences in the first place, as well as professional competences (i.e. planning strategies, teaching methods, and mechanisms to implement them) and ultimately personal competences (i.e. physical health, general intelligence, moral behaviour, language and communication skills, and abilities to innovate, manage and make decisions). On the other hand, Velasco and Tójar (2018) defined three generic groups of competences: instrumental (cognitive, methodological, digital, and language skills), interpersonal (personal and social skills) and systemic competences (managerial and research skills, autonomy, and adaptability).

Alqiawi and Ezzeldin (2015) ultimately state that the unification of university teachers' competences, i.e. different skills and abilities in their understanding, is a form of social demand, which is, however, unrealistic for certain reasons. Competences cannot be unified and updated due to constant procedural changes in teacher training (doctoral studies), the specificity of each university environment, the individuality of students, and the influence of psychology and other disciplines on the education of university teachers.

\section{Methodology}

The aim of the systematic review was to find, analyse and summarise theoretical and empirical studies published about university teachers' competences over the last 10 years. Given that the topic of competences is relatively broad, we aimed at further investigating the specific areas the studies cover, the types of competences that are the subject of the studies, the types of research and designs covering the area, the research methods and tools used by the study authors, the scale in which the standardised tools are used, and the empirical studies' conclusions.

The literary sources were collected through the international electronic databases Web of Science (WOS) and Scopus, using the following keywords: "higher education teacher", "university teacher", "competence" and "competence profile". Selection criteria also limited the sources to openaccess, and published in English 2010-2020.

The search and selection criteria identified 192 literary sources (97 published in the Scopus database and 95 in WOS). In the first stage of data collection we excluded duplicities ( 34 sources) and those with different/irrelevant content based on the abstract review (107 sources). The second stage of data collection consisted of reading the full version of 51 articles. We further ruled out 16 articles with irrelevant content, i.e. studies on development of university students' competences (12) or those of doctoral students (4). The final version of our literature survey includes 35 sources.

Table 1 offers an overview of the studies analysed in our database. First, we summarised the selected studies' types of research and designs. Of the total number of studies (35), 15 were theoretical and 20 empirical. Then we categorised them according to location or country, and year of publication.

Table 1: Overview of Studies

\begin{tabular}{|c|c|c|}
\hline \multirow{7}{*}{$\begin{array}{l}\text { Research } \\
\text { type } \\
\text { and design }\end{array}$} & \multirow{4}{*}{ Theoretical studies (15) } & Literature review (6) \\
\hline & & Literature survey (5) \\
\hline & & Theoretical research (creating competence models) (2) \\
\hline & & Theoretical research (creating training programmes) (2) \\
\hline & \multirow{3}{*}{ Empirical studies (20) } & Qualitative design (4) \\
\hline & & Quantitative design (9) \\
\hline & & Mixed design (7) \\
\hline
\end{tabular}




\begin{tabular}{|c|c|c|}
\hline \multirow{5}{*}{$\begin{array}{l}\text { Geographical } \\
\text { area }\end{array}$} & Europe (26) & $\begin{array}{l}\text { Spain (7), Russia (6), Slovakia (4), Germany (2), Sweden (1), Italy (1), } \\
\text { Finland (1), Czech Republic (1), Romania (1), Netherlands (1), Portugal (1) }\end{array}$ \\
\hline & Asia (4) & Kazakhstan (2), Uzbekistan (2) \\
\hline & Africa (2) & Nigeria (1), South Africa (1) \\
\hline & South America (2) & Ecuador (2) \\
\hline & North America (1) & Mexico (1) \\
\hline \multirow{3}{*}{$\begin{array}{l}\text { Year of } \\
\text { publication }\end{array}$} & $2020(13)$ & $2017(5)$ \\
\hline & $2019(5)$ & $2016(2)$ \\
\hline & $2018(1)$ & $2015(2)$ \\
\hline
\end{tabular}

\section{Results}

Table 2 categorises studies by the type of competences they address. In total, we identified 13 types of competences, and ranked them according to the number of studies examining them. Table 3 offers an overview of research methods and tools used in empirical studies with quantitative, qualitative, and mixed design. The studies are categorised by the types of competences examined by the given research, and are arranged chronologically according to the number of studies within the given group and the year of publication.

Table 2: Literature overview by type of competences

\begin{tabular}{|l|l|l|l|}
\hline & Digital (10) & Social (2) & Personality (1) \\
Competence & Pedagogical (7) & $\operatorname{ESD}^{*}(2)$ & Research (1) \\
& Professional (5) & Key (1) & Organisational and managerial (1) \\
& Intercultural (2) & Inclusive education (1) & $\begin{array}{l}\text { Methodical (1) } \\
\text { Information and communication (1) }\end{array}$ \\
\hline
\end{tabular}

${ }^{*}$ Education for Sustainable Development

Table 3: Overview of empirical studies by the type of competences

\begin{tabular}{|c|c|c|c|c|c|c|c|}
\hline Study & Design & $\begin{array}{l}\text { Research method } \\
\text { and tool }\end{array}$ & Research goal & $\begin{array}{l}\text { Dimensions and tool } \\
\text { items }\end{array}$ & Scale & $\begin{array}{l}\text { Relia- } \\
\text { bility }\end{array}$ & Set \\
\hline \multicolumn{8}{|c|}{ Digital competences } \\
\hline \multirow{2}{*}{$\begin{array}{l}\text { González- } \\
\text { Sanmamed, et } \\
\text { al., } 2014\end{array}$} & \multirow[b]{2}{*}{ Quantitative } & \multirow[b]{2}{*}{$\begin{array}{l}\text { Original online } \\
\text { questionnaire }\end{array}$} & To analyse level of proficiency & \multirow[b]{2}{*}{36 items } & \multirow{2}{*}{$\begin{array}{l}\text { 5-point } \\
\text { Likert } \\
\text { scale }\end{array}$} & $\begin{array}{l}\alpha= \\
0.987\end{array}$ & \multirow[b]{2}{*}{$\begin{array}{l}166 \\
\text { teachers }\end{array}$} \\
\hline & & & $\begin{array}{l}\text { To identify professional } \\
\text { development needs required to } \\
\text { improve digital competences }\end{array}$ & & & $\begin{array}{l}\alpha= \\
0,990\end{array}$ & \\
\hline $\begin{array}{l}\text { Sjöberg, Lilja, } \\
2019\end{array}$ & $\begin{array}{l}\text { Mixed } \\
\text { methods }\end{array}$ & $\begin{array}{l}\text { Original online } \\
\text { questionnaire } \\
\text { Focus group }\end{array}$ & $\begin{array}{l}\text { To identify teachers' level of } \\
\text { competence and utilisation of } \\
\text { digital technology in their } \\
\text { teaching }\end{array}$ & $\begin{array}{l}\text { 1 technical knowledge } \\
\text { 2.skillful application of } \\
\text { technology } \\
\text { 3. ability to develop } \\
\text { appropriate and context- } \\
\text { specific strategies }\end{array}$ & $\begin{array}{l}\text { 4-point } \\
\text { Likert } \\
\text { scale }\end{array}$ & - & $\begin{array}{l}254+6 \\
\text { teachers }\end{array}$ \\
\hline $\begin{array}{l}\text { Ruiz-Cabezas et } \\
\text { al., } 2020\end{array}$ & $\begin{array}{l}\text { Mixed } \\
\text { methods }\end{array}$ & $\begin{array}{l}\text { Original } \\
\text { questionnaire } \\
\text { Focus group }\end{array}$ & $\begin{array}{l}\text { To analyse use and importance } \\
\text { of ICT resources by teachers to } \\
\text { improve teaching-learning } \\
\text { process. Use of questionnaire }\end{array}$ & $\begin{array}{l}\text { 1.Command of theoretical } \\
\text { knowledge, } \\
2 \text { Practical understanding or } \\
\text { projection of acquired } \\
\text { competence } \\
\text { 3.Personal motivation/ } \\
\text { identification with } \\
\text { competence }\end{array}$ & $\begin{array}{l}\text { 6-point } \\
\text { Likert } \\
\text { scale }\end{array}$ & $\begin{array}{l}\alpha= \\
0,945\end{array}$ & $\begin{array}{l}30+16 \\
\text { teachers }\end{array}$ \\
\hline $\begin{array}{l}\text { Dias-Trindade } \\
\text { et al., } 2020\end{array}$ & Quantitative & $\begin{array}{l}\text { Self-assessment tool } \\
\text { "DigCompEdu } \\
\text { CheckIn" }\end{array}$ & $\begin{array}{l}\text { To evaluate digital competence } \\
\text { level of higher education } \\
\text { teachers }\end{array}$ & $\begin{array}{l}\text { 1 Educators' professional } \\
\text { competences } \\
\text { 2.Educators' pedagogic } \\
\text { competences } \\
3 \text { Learners' competences } \\
\text { +6 sub-dimensions and } 21 \\
\text { competences }\end{array}$ & $\begin{array}{l}\text { 5-point } \\
\text { Likert } \\
\text { scale }\end{array}$ & $\begin{array}{l}\alpha= \\
0,938\end{array}$ & $\begin{array}{l}118 \\
\text { teachers }\end{array}$ \\
\hline
\end{tabular}




\begin{tabular}{|c|c|c|c|c|c|c|c|}
\hline Study & Design & \begin{tabular}{|l|} 
Research method \\
and tool
\end{tabular} & Research goal & $\begin{array}{l}\text { Dimensions and tool } \\
\text { items }\end{array}$ & Scale & $\begin{array}{l}\text { Relia- } \\
\text { bility }\end{array}$ & Set \\
\hline \multirow[b]{2}{*}{$\begin{array}{l}\text { Mirete et al., } \\
2020\end{array}$} & \multirow[b]{2}{*}{ Quantitative } & $\begin{array}{l}\text { "CEE" questionnaire } \\
\text { on teaching } \\
\text { approaches }\end{array}$ & \multirow{2}{*}{$\begin{array}{l}\text { To identify causal relationship } \\
\text { between university teachers' } \\
\text { strategies and intentions and } \\
\text { their ICT competence }\end{array}$} & 16 items & \multirow[b]{2}{*}{$\begin{array}{l}\text { 5-point } \\
\text { Likert } \\
\text { scale }\end{array}$} & $\alpha=$ & \multirow[b]{2}{*}{$\begin{array}{l}186 \\
\text { teachers }\end{array}$} \\
\hline & & \begin{tabular}{|l|} 
"ACUTIC" \\
questionnaire to \\
assess attitude, \\
knowledge, and use \\
of ICT
\end{tabular} & & \begin{tabular}{|l} 
1. attitudes toward use of \\
ICT \\
2. knowledge of ICT \\
3. use of ICT \\
+31 items \\
\end{tabular} & & $\begin{array}{l}\alpha= \\
o, 917\end{array}$ & \\
\hline \multicolumn{8}{|c|}{ Pedagogical competences } \\
\hline $\begin{array}{l}\text { Dută, Rafaila, } \\
2014\end{array}$ & Quantitative & $\begin{array}{l}\text { Original } \\
\text { questionnaire }\end{array}$ & $\begin{array}{l}\text { To analyse perception on } \\
\text { importance of teaching activity } \\
\text { and level of competences } \\
\text { needed for activities with } \\
\text { students }\end{array}$ & 14 items & - & - & $\begin{array}{l}485 \\
\text { teachers }\end{array}$ \\
\hline $\begin{array}{l}\text { Perez-Poch, } \\
\text { López, } 2016\end{array}$ & Quantitative & $\begin{array}{l}\text { Original online } \\
\text { questionnaire }\end{array}$ & $\begin{array}{l}\text { To assess importance of } \\
\text { pedagogical competences in } \\
\text { suggested competence model }\end{array}$ & $\begin{array}{l}55 \text { items ( } 6 \text { competences + } \\
49 \text { indicators) }\end{array}$ & \begin{tabular}{|l|} 
4-point \\
Likert \\
scale
\end{tabular} & - & $\begin{array}{l}2347 \\
\text { teachers }\end{array}$ \\
\hline $\begin{array}{l}\text { Okolie et al., } \\
2020\end{array}$ & $\begin{array}{l}\text { Mixed } \\
\text { methods }\end{array}$ & $\begin{array}{l}\text { Original } \\
\text { questionnaire } \\
\text { Focus group }\end{array}$ & $\begin{array}{l}\text { To investigate if teachers with } \\
\text { pedagogical training in addition } \\
\text { to their PhD qualification } \\
\text { possess higher pedagogical } \\
\text { competences }\end{array}$ & 13 items & - & $\begin{array}{l}\alpha= \\
o, 85\end{array}$ & $\begin{array}{l}1174+9 \\
\text { teachers }\end{array}$ \\
\hline \multicolumn{8}{|c|}{ Professional competences } \\
\hline $\begin{array}{l}\text { Ellerani, } \\
\text { Mendoza, } 2013\end{array}$ & $\begin{array}{l}\text { Mixed } \\
\text { methods } \\
\text { Action- } \\
\text { research }\end{array}$ & \begin{tabular}{|l|} 
"Human Resource \\
Management" tool, \\
"Edulife \\
Foundation" E- \\
Portfolio tool, \\
Textual analysis \\
with Taltac software
\end{tabular} & $\begin{array}{l}\text { To define a competence profile } \\
\text { of university teachers and to } \\
\text { realise an e-portfolio system to } \\
\text { continuously improve new } \\
\text { teachers' profile }\end{array}$ & - & - & - & $\begin{array}{l}13 \\
\text { institu- } \\
\text { tions }\end{array}$ \\
\hline $\begin{array}{l}\text { Semrádová, } \\
\text { Hubáčková, } 2014\end{array}$ & Qualitative & \begin{tabular}{|l|} 
Students' reflections \\
(from essays and \\
seminar papers)
\end{tabular} & $\begin{array}{l}\text { To analyse students' notion of } \\
\text { competences and features } \\
\text { required of university teachers }\end{array}$ & - & - & - & $\begin{array}{l}348 \\
\text { students }\end{array}$ \\
\hline $\begin{array}{l}\text { Blašková et al., } \\
2014\end{array}$ & Qualitative & $\begin{array}{l}\text { Questionnaire with } \\
\text { open-ended } \\
\text { questions }\end{array}$ & $\begin{array}{l}\text { To analyse which competences } \\
\text { university teachers should } \\
\text { certainly not have and to create } \\
\text { a competence model }\end{array}$ & - & - & - & $\begin{array}{l}686 \\
\text { students }\end{array}$ \\
\hline \multicolumn{8}{|c|}{ Intercultural competences } \\
\hline $\begin{array}{l}\text { Fernández- } \\
\text { Agüero, } \\
\text { Chancay- } \\
\text { Cedeño, 2019 }\end{array}$ & Quantitative & $\begin{array}{l}\text { Original } \\
\text { questionnaire }\end{array}$ & $\begin{array}{l}\text { To identify how university } \\
\text { teachers of English as a foreign } \\
\text { language cope with intercultural } \\
\text { teaching practice }\end{array}$ & \begin{tabular}{|l|} 
Dimensions of IC in Byram's \\
Model (1997): 1. knowledge \\
2. attitude \\
3. skills \\
\end{tabular} & $\begin{array}{l}\text { 4-point } \\
\text { Likert } \\
\text { scale }\end{array}$ & 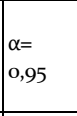 & $\begin{array}{l}68 \\
\text { teachers }\end{array}$ \\
\hline \multirow{2}{*}{$\begin{array}{l}\text { Zelenková, } \\
\text { Hanesová, } 2019\end{array}$} & \multirow{2}{*}{$\begin{array}{l}\text { Mixed } \\
\text { methods }\end{array}$} & $\begin{array}{l}\text { Original } \\
\text { questionnaire }\end{array}$ & $\begin{array}{l}\text { To define need for intercultural } \\
\text { competence of university } \\
\text { teachers }\end{array}$ & 9 multiple-choice questions & & \multirow[b]{2}{*}{-} & $\begin{array}{l}185+218 \\
\text { teachers }\end{array}$ \\
\hline & & Action research & $\begin{array}{l}\text { To share results from action } \\
\text { research while piloting an } \\
\text { intercultural competence course }\end{array}$ & - & & & $\begin{array}{l}20 \\
\text { teachers }\end{array}$ \\
\hline \multicolumn{8}{|c|}{ Personality competences } \\
\hline $\begin{array}{l}\text { Blašková et al., } \\
2014\end{array}$ & $\begin{array}{l}\text { Mixed } \\
\text { methods }\end{array}$ & $\begin{array}{l}\text { Focus group } \\
\text { Original } \\
\text { questionnaire }\end{array}$ & $\begin{array}{l}\text { To analyse and define } \\
\text { university teachers' key } \\
\text { personality competences }\end{array}$ & - & \begin{tabular}{|l|} 
po- \\
point \\
Likert \\
scale \\
\end{tabular} & - & \begin{tabular}{|l|}
27 \\
teachers \\
+395 \\
students \\
\end{tabular} \\
\hline \multicolumn{8}{|l|}{ Key competences } \\
\hline $\begin{array}{l}\text { Blašková et al., } \\
2015\end{array}$ & Quantitative & $\begin{array}{l}\text { Original } \\
\text { questionnaire }\end{array}$ & $\begin{array}{l}\text { To analyse teachers' motivation } \\
\text { for developing key competences }\end{array}$ & $\begin{array}{l}15 \text { questions (12 closed+3 } \\
\text { opened) }\end{array}$ & \begin{tabular}{|l|} 
5-point \\
Likert \\
scale
\end{tabular} & - & $\begin{array}{l}108 \\
\text { teachers }\end{array}$ \\
\hline \multicolumn{8}{|c|}{ Social competences } \\
\hline $\begin{array}{l}\text { Gridneva et al., } \\
2017\end{array}$ & Quantitative & \begin{tabular}{|l|} 
Resilience test \\
"Hardiness Survey". \\
Social competence \\
technique by N.V. \\
Kalinina \\
\end{tabular} & $\begin{array}{l}\text { To study interrelation between } \\
\text { teachers' resilience and social } \\
\text { competence. }\end{array}$ & - & - & - & $\begin{array}{l}102 \\
\text { teachers }\end{array}$ \\
\hline \multicolumn{8}{|c|}{ Education for Sustainable Development (ESD) competences } \\
\hline $\begin{array}{l}\text { Scherak, } \\
\text { Rieckmann, } \\
2020\end{array}$ & $\begin{array}{l}\text { Mixed } \\
\text { methods }\end{array}$ & \begin{tabular}{|l} 
Focus group \\
Self-evaluation and \\
feedback survey
\end{tabular} & $\begin{array}{l}\text { To investigate if training } \\
\text { programme enhanced ESD } \\
\text { competences }\end{array}$ & - & \begin{tabular}{|l|} 
5-point \\
Likert \\
scale
\end{tabular} & & $\begin{array}{l}6+9 \\
\text { teachers }\end{array}$ \\
\hline
\end{tabular}




\begin{tabular}{|c|c|c|c|c|c|c|c|}
\hline Study & Design & \begin{tabular}{|l|} 
Research method \\
and tool
\end{tabular} & Research goal & $\begin{array}{l}\text { Dimensions and tool } \\
\text { items }\end{array}$ & Scale & \begin{tabular}{|l|} 
Relia- \\
bility
\end{tabular} & Set \\
\hline \multicolumn{8}{|c|}{ Competences for inclusive education } \\
\hline Ke et al., 2017 & Qualitative & \begin{tabular}{|l|} 
Pedagogical \\
experiment, \\
"Index of tolerance" \\
questionnaire, I. \\
Yusupov \\
"Ability to \\
Empathize" \\
questionnaire \\
\end{tabular} & $\begin{array}{l}\text { To determine quality of teachers' } \\
\text { psychological competence to } \\
\text { work in inclusive education } \\
\text { environment and to implement } \\
\text { and verify teachers' advanced } \\
\text { training programme }\end{array}$ &.$^{-}$ & - & l- & $\begin{array}{l}19 \\
\text { teachers }\end{array}$ \\
\hline \multicolumn{8}{|c|}{ Research competences } \\
\hline \multirow{3}{*}{$\begin{array}{l}\text { Koshmaga- } \\
\text { nbetova et al., } \\
2020\end{array}$} & \multirow{3}{*}{ Quantitative } & \multirow{3}{*}{\begin{tabular}{|l|} 
Modified CETL- \\
AURS questionnaire \\
developed by Centre \\
for Excellence in \\
Teaching and \\
Learning, for \\
Applied Student \\
Research Skills \\
\end{tabular}} & \multirow{3}{*}{$\begin{array}{l}\text { To evaluate perception and } \\
\text { perspectives of teachers' } \\
\text { research competences } \\
\text { (transferable research skills, } \\
\text { research-specific skills, research } \\
\text { experience, attitude, and } \\
\text { motivation to conduct research) }\end{array}$} & General skills & \begin{tabular}{|l|}
$10-$ \\
point
\end{tabular} & $\begin{array}{l}\alpha= \\
o, 94\end{array}$ & \multirow{3}{*}{$\begin{array}{l}90 \\
\text { teachers }\end{array}$} \\
\hline & & & & Specific skills & \begin{tabular}{|l} 
Likert \\
scale
\end{tabular} & $\begin{array}{l}\alpha= \\
o, 93\end{array}$ & \\
\hline & & & & $\begin{array}{l}\text { Motivation to participate in } \\
\text { research }\end{array}$ & $\begin{array}{l}\text { 7-point } \\
\text { scale }\end{array}$ & $\begin{array}{l}\alpha= \\
o, 84\end{array}$ & \\
\hline \multicolumn{8}{|c|}{ Organisational or managerial competences } \\
\hline $\begin{array}{l}\text { Solovova, } \\
\text { Sukhankina, } \\
2020\end{array}$ & Qualitative & Self-assessment tool & \begin{tabular}{|l|} 
To prepare and assess \\
methodical support for \\
developing organisational and \\
managerial competence under \\
advanced training programme
\end{tabular} & - & - & - & $\begin{array}{l}140 \\
\text { teachers }\end{array}$ \\
\hline
\end{tabular}

Digital competences were the subject of three quantitative research and two mixed design research projects. Quantitative research by González-Sanmamed et al. (2014) points to the interest of teachers in the job-related enhancement of digital competences, with questionnaire measurement results demonstrating that under the individual competences, the average response value related to the variable "professional development needs" was significantly higher than the value of the variable "level of proficiency". Similar conclusions were reached by Dias-Trindade et al. (2020). In their quantitative research they emphasize the need to increase the level of digital competences, as the results of standardised measurement show university teachers have a middling level of this type of competence, with a score of 41 out of a maximum of 84 points. While competences related to the use of digital media, the use of digital media for professional cooperation, and the use of digital technologies in teaching scored very high, competences related to guiding students in the digital environment, analysing available information for assisting, and guiding them to responsible use of digital technologies scored very low. Ultimately Mirete et al. (2020) discussed the relatively specific topic of digital competences in their study, using quantitative design and two standardised questionnaires. Based on their findings, the teaching strategies of university teachers precondition the use of digital technologies and related competences. The study results confirmed a positive and statistically significant relationship between the "Knowledge Building Approach" and the use of digital technologies, as well as a statistically significant but negative relationship between the use of these technologies and the "Info Transmission Approach". The study also points out that so far there is no research suggesting causal relationship between teaching approaches and the level of digital competences achieved.

Another two mixed design studies focused on digital competences, with the authors of a 2019 study, Sjöberg and Lilja, aiming at mapping teachers' achieved level of digital competences and identifying areas of development to support them. The results of questionnaire assessment, combined with the opinions of a discussion group, showed that teachers' self-assessment of their digital competences is very positive. However in reality they do not apply this knowledge in their teaching and are not sufficiently secure in using new technologies in the teaching process. Ultimately, the research suggests that although teachers are generally positive regarding technological development, they have concerns that the use of digital technologies is undermining the purpose and pedagogical practices of teaching. The second study using a mixed research design was by Ruiz-Cabezas et al. 
(2020). The authors created a design for a measurement tool to be used primarily for analysing the level of digital competences, specifically focusing on the use of digital technologies. A secondary objective of the device is to determine the importance teachers attribute to digital competences. The qualitative study design with a modified questionnaire included content analysis of the collected open answers (opinions) of 30 teachers and of the written records of two 8-member discussion groups.

Pedagogical competences were the subject of three studies, two with quantitative design and one with a mixed design. In their comparative study published in 2014, Dută and Rafaila expanded a previous research project's sample from 2008-2009, originally including 240 Spanish teachers, by 245 university teachers from Romania. The questionnaire results point to discrepancies between the degree of importance teachers attribute to individual activities they deploy in the educational process and the achieved level of teacher competences. Statistically significant differences between "degree of importance" and "level of competence" were identified in five of the seven activities assessed in the sample of Romanian teachers and in four of the seven activities assessed by Spanish teachers.

Perez-Poch and López (2016) authored another study in the field of pedagogical competences, following up on their research from 2003 aimed at creating a competence model for university teachers using discussion group outputs by 64 teachers. In the latter study the authors mapped the views of 2,347 teachers on the competence model. According to the findings, teachers consider the communication competences the most important, while interpersonal, methodological, planning and management competences are also of relatively high importance. Competences related to the innovativeness were seen as the worst, while teamwork competences were second worst.

Last but not least, in 2020, Okolie et al. conducted research using questionnaires on a sample of 1,174 teachers, followed by two focus groups (9 participants each). The project focused on pedagogical competences and their possible enhancement through additional pedagogical training. The research results offer promising findings, as a statistically significant difference was found between the level of competences achieved by teachers who received pedagogical training additional to their doctoral studies and competences of teachers without any additional pedagogical training. The authors emphasize the essence of change in the professional development of university teachers is the need for continuous learning and development of pedagogical competences, as it was shown that teachers who received additional pedagogical training better teach effectively, facilitate student learning, and apply appropriate and effective teaching approaches and strategies. Conversely, the authors dismiss doctoral study as a sufficient pedagogical qualification a teacher can rely on throughout his or her career.

Professional competences were also the subject of interest in three research projects with qualitative, quantitative, and mixed design. In 2013, Ellerani and Mendoza carried out relatively extensive research with mixed design aimed at making a competence profile of university teachers, and further creating, testing, and evaluating an "e-portfolio system" to provide continuous support for enhancing its quality and further development. This action research involved 13 universities and more than 700 teachers. Research tools included questionnaires, text content analysis, and video recordings.

Two similar qualitative research projects on professional competences from 2014 focused on students' reflections and views on the competences of university teachers. Semrádová and Hubáčková (2014) collected reflections of students from 2009 to 2013. Their analysis concluded that participants in their study attribute importance mainly to competences related to communication, teamwork, creativity, critical thinking, problem solving, enhancement of students' independence, and ability for reflection and self-reflection. Students emphasised the essential importance of university teachers' personal and pedagogical qualities; on the other hand, there was an absence of competences related to scientific and professional as well as organisational and managerial activities. The authors of the second research, Blašková et al. (2014), followed up on the first stage of their research on a sample of 395 students, which examined what type of competences teachers should possess. In the second stage of the project, they focused on reflections and opinions of 686 students on the types of competences 
a university teacher should definitely not possess. In this case, the students yet again primarily focused on personality traits and prerequisites, most often stating that teachers ought not to be biased or unfair, arrogant, conceited, or act unprofessionally or lack knowledge in their field. A competence profile, defining and describing 7 competences and particularly their behavioural indicators (positive and negative), is an important study outcome.

Intercultural competences were the subject of quantitative research carried out in 2019 (Fernández-Agüero, Chancay-Cedeño). It suggested the need to develop such competences in teachers who teach in English, as teachers mainly develop intercultural attitudes in their pedagogical practice, but do not enhance their knowledge or skills with a view to raising intercultural awareness. This action research also criticizes the lack of attention and importance teachers give to other foreign cultures. Another mixed design research project on this topic was implemented one year later (Zelenková, Hanesová, 2019). Its authors argue the importance of teachers' intercultural competences in the context of growing pressure associated with the support of international cooperation at universities. An analysis of teachers' needs, carried out through questionnaire measurement in 2011 and 2018, preceded a draft new curriculum of a course on intercultural competences with the aim of developing language, intercultural, and pedagogical competences. This action research took place during a pilot testing of a course for 20 teachers. As a result the authors concluded that the implementation of a new curriculum designed on the basis of pre-identified teacher needs is an appropriate and supportive way to enhance intercultural competences, since the majority of teachers was ready to implement the new curriculum's innovative methods in practice.

The aim of the qualitative part of the mixed-design research with the central focus on personal competences (Blašková et al., 2014) was to define a set of teachers' competences during three focus groups with 27 members. The authors then designed a questionnaire for the quantitative part of the research with the intention of mapping students' views on personal competences (open-ended question) and also of finding the relative importance they attribute to 10 competences defined by the qualitative research. Research participants defined professionalism, fairness, and communication skills as the three most important competences in this category. Simultaneously, the three highest rated personality competences of teachers under the proposed competence model were personalities with excellent teaching competences, professional personality, and mature personality. Conversely, categories like good and acclaimed author, critically thinking personality or personality with valuable scientific efforts are not sufficiently visible for students, hence they perceive them less intensely or to a minimal extent.

In quantitative research design, Blašková et al. (2015) focus on key competences. The questionnaire-based work points to a relatively high level of teachers' motivation for quality education and objective evaluation of students, but slightly lower motivation to enhance their own competences. The authors' also suggest methods how to develop key competences, which in their understanding are mainly pedagogical, professional, and communication-related.

Quantitative research by Gridnev et al. (2017) also focused on social competences. The authors drew attention to the personality of a university teacher and examined the relationship between resilience and social competences through two standardised questionnaires. The results of the research showed a statistically significant relationship between the examined components, i.e. the higher the level of teachers' social competences in difficult stressful situations, the higher the value of their resilience. The authors conclude social competence in difficult life situations is the most important source of teacher resilience.

In their study, Scherak and Rieckmann (2020) addressed the concept of "Education for Sustainable Development" (ESD), which they define as interconnected approaches from environmental, development, peace, and political education. Over the course of two years, a series of workshops and teacher training was held at a university in Germany to develop competences focused on the ESD concept using the competence framework created under the auspices of the Erasmus + "A Rounder Sense of Purpose" project. The authors of the study examined the effectiveness of training through focus groups and a self-assessment tool, and based on the results concluded this concept of training is not a suitable tool for education, since a deeper and more reflective process is needed to 
develop actual competences.

Qualitative research by Ziken et al. (2017) focused on competences for inclusive education; this was the only research from our literature review using a pedagogical experiment. In the first stage of the research the authors used standardised questionnaire measurements. The results in the empathy test among participating teachers $(n=19)$ were at the average level and below average level in the test of tolerance. The study also included a relatively detailed teacher training programme plan implemented with the aim of developing and supporting competences particularly important for working with students with health limitations, with the authors subsequently experimentally verifying its effectiveness. Prior to completing the training programme, up to $58.9 \%$ of teachers ranked very low in psychological competences, $28.7 \%$ reached a medium level and $12.3 \%$ a high level, while after completing training the level of teachers' competences increased, with an average of $13 \%$ of teachers at a low level, $60.9 \%$ medium and $26 \%$ high level.

Research competences were the subject of quantitative research by Koshmaganbetova et al. (2020), using a standardised questionnaire, modified to map the research competences of university teachers. A full $71 \%$ of participants demonstrated high motivation in conducting research, while teachers with a higher perceived level of research competences were more motivated to carry out research. The research also demonstrated that men achieved a higher level of competence than women in the areas of transmitted information collection skills, information evaluation, and problem solving.

Finally, Solovova and Sukhankina (2020) focused on relatively little discussed organisational or managerial competences. Based on the confirmation and justification of the nature of competences of this kind within the results of an empirical study conducted in 2017-2019, drawing on analysis of 280 university teachers' opinions, they designed a draft methodological procedure with the aim of developing these competences. Competence development methods were later evaluated on a sample of 140 teachers who led an Educational Program Management programme and evaluated the development of four components of organisational and managerial competences.

Table 4: Competence model review

\begin{tabular}{|c|c|c|}
\hline $\begin{array}{l}\text { Authors of the } \\
\text { model }\end{array}$ & Competences & \\
\hline \multirow{2}{*}{$\begin{array}{l}\text { Pérez, Torelló, } 2012 \\
\text { Pedagogical } \\
\text { competences profile }\end{array}$} & $\begin{array}{l}\text { 1. Designing the Teaching Guide according to student } \\
\text { needs, context, and professional profile, } \\
\text { in coordination with other professionals } \\
\text { 2. Conducting the learning process fostering individual } \\
\text { and collaborative learning opportunities } \\
\text { 3. Tutoring students' learning process, promoting } \\
\text { activities to achieve more autonomy }\end{array}$ & $\begin{array}{l}\text { 4. Evaluating the learning process } \\
\text { 5. Contributing actively to the improvement of } \\
\text { teaching } \\
\text { 6. Participating actively in the academic and } \\
\text { organisational dynamics of the institution }\end{array}$ \\
\hline & $\begin{array}{l}\text { 1. Planning and designing face-to-face learning } \\
\text { experiences, blended and virtual environments } \\
\text { 2. Developing and conducting collaborative face-to-face } \\
\text { learning experiences, blended and virtual environments } \\
\text { 3. Face-to-face tutoring and assessment of knowledge } \\
\text { construction processes, blended and virtual } \\
\text { environments }\end{array}$ & $\begin{array}{l}\text { 4. Managing of growth and professional } \\
\text { development with the support of ICT } \\
\text { 5. Pedagogical research, development, and } \\
\text { innovation with/for ICT in education } \\
\text { 6. Diversity, ethics, and responsible use of ICT } \\
\text { in teachers' professional development } \\
\text { 7. Environmental concerns, labour health and } \\
\text { safety in the use of ICT in the teaching } \\
\text { profession }\end{array}$ \\
\hline $\begin{array}{l}\text { Blašková et al., } \\
2014\end{array}$ & $\begin{array}{l}\text { 1. Professional competence } \\
\text { 2. Educational competence } \\
\text { 3. Motivational competence } \\
\text { 4. Communicational competence }\end{array}$ & $\begin{array}{l}\text { 5. Personal competence } \\
\text { 6. Science \& research competence } \\
\text { 7. Publication competence }\end{array}$ \\
\hline $\begin{array}{l}\text { Blašková et al., } \\
2015 \\
\text { Personality } \\
\text { competences } \\
\text { profile }\end{array}$ & $\begin{array}{l}\text { 1. Morally and ethically acting personality } \\
\text { 2. Professional personality } \\
\text { 3. Personality with valuable scientific effort } \\
\text { 4. Acclaimed author and honest personality } \\
\text { 5. Personality with excellent teaching competences }\end{array}$ & $\begin{array}{l}\text { 6. Personality acting as a role model } \\
\text { 7. Mature personality } \\
\text { 8. Critically thinking personality } \\
\text { 9. Sophisticated and communicating } \\
\text { personality } \\
\text { 10. Progressive, highly motivated, and always } \\
\text { motivating personality }\end{array}$ \\
\hline
\end{tabular}




\begin{tabular}{|l|l|l|}
\hline $\begin{array}{l}\text { Authors of the } \\
\text { model }\end{array}$ & Competences & \\
\hline $\begin{array}{l}\text { Perez-Poch, López, } \\
2016\end{array}$ & $\begin{array}{l}\text { 1. Interpersonal competence } \\
\text { 2. Methodological competence } \\
\text { 3. Communicative competence }\end{array}$ & $\begin{array}{l}\text { 4. Planning and management competence } \\
\text { 5. Teamwork competence } \\
\text { 6. Innovation competence }\end{array}$ \\
\hline $\begin{array}{l}\text { Fakhrutdi-nova et } \\
\text { al., 2o20 }\end{array}$ & $\begin{array}{l}\text { 1. Value-semantic competences } \\
\text { 2. General cultural competences } \\
\text { 3. Educational and cognitive competences } \\
\text { 4. Informational competence }\end{array}$ & $\begin{array}{l}\text { 5. Communicative competences } \\
\text { 6. Socio-labour competence } \\
\text { 7. Personal self-improvement competences }\end{array}$ \\
\hline
\end{tabular}

Table 4 offers an overview of the competence models that were part of the studies analysed in our literature review. The proposed competence models and pedagogical and digital profile of Pérez and Torelló (2012) were part of the theoretical research, for part of which the authors designed a questionnaire to identify needs in the field of digital competence development. The studies by Blašková et al. (2014), Blašková et al. (2015) and Perez-Poch and López (2016) were already defined in Table 3, as they included empirical research and in the case of Perez-Poch and López (2016) also a qualitative evaluation of a draft competence model by teachers.

\section{Discussion}

The aim of this study was to offer an analysis of published studies in the field of university teachers' competences based on pre-established criteria of source selection. Ultimately, we analysed 35 studies relevant to our topic out of the originally selected 192, primarily identified by type of research and design. 15 theoretical studies included 6 literature surveys, 5 survey studies and 4 theoretical research projects, 2 of which focused on designing a competence profile and 2 on designing a training programme. Of the total 20 empirical studies, 4 were qualitative, 9 were quantitative, and 7 were of mixed design. The studies were categorised based on the geographical area or country of publishing, with the analysis showing most of them being published in Europe (26).

Studies were further categorised primarily by the topic or type of competences. We identified 12 types of competences, with the largest part of studies (10 in total: 5 empirical, 2 literature surveys, 2 survey studies, and 1 theoretical research) focused on digital competences. All empirical studies published on digital competences opted for a questionnaire as a research tool, using it to map the level of teachers' digital competences. Esteve-Mon et al. (2020), the authors of one of the analysed studies, conclude that technological advances have been so integrated into the environment of higher education institutions that teachers' digital competences have become a leading and integral part of the teachers' competence profile in recent years, mainly after the outbreak of the Covid-19 pandemic. We thus conclude that this situation, which has necessarily transformed especially higher education in the online world, may be why teachers' digital competences have become such a widely discussed topic: 5 out of 10 studies published since the end of 2019 subject to our analysis focused on this topic. Likewise, most analysed studies from 2020 focused on digital competences.

Studies on pedagogical competences were the second most frequently published in our sample, as we analysed 7 studies in this area ( 3 empirical, 2 literature surveys, 1 review study, and 1 theoretical research focused on designing a competence profile).

Various authors (Fakhrutdinova et al., 2020; Okolie et al., 2020; Winberg et al., 2018; Merkt 2017) agree that pedagogical competences are given insufficient attention and in general criticize the inadequate number of research projects that could present the substance of these competences. Intriguingly, the critical conclusions of their studies suggest pedagogical competences, or educational activity in general, has been recently pushed aside, with a strong emphasis currently put on research, science, and related competences. Fakhrutdinova et al. (2020) believe that unfortunately the professional training of university teachers in regards to their pedagogical competences is often not considered a sufficient priority by the teachers themselves in this context, thus it is not their immediate interest either. The authors further argue that the consequence of pedagogical education 
not being a required precondition for entering employment results in an insufficient level of pedagogical competences among teachers. Those competences are then not perceived as an objective quality indicator, unlike professional or research competences. Statistical data also supports these arguments: a full $73 \%$ of university teachers have no pedagogical education (Dneprov et al., 2017; in Fakhrutdinova et al., 2020). In this regard, Okolie et al. (2020), the authors of one of the research projects examined in this survey, present the need for continuous development of pedagogical competences. They incline to believe that university teachers should have pedagogical education, arguing that knowledge of higher education pedagogy is a key determinant of teaching.

Professional competences were the third most discussed topic of studies subject to our analysis: 5 altogether ( 3 empirical, 1 literature review, 1 review study), with two of the three empirical studies dealing with students' opinions and reflections. The authors of these studies agreed on the results and also confirmed the relevance of defining and unifying the profile of a university teacher based on professional competences. Intercultural, social and ESD competences were each the subject of two studies. In this context we want to focus on relatively unknown ESD competences, since they are a relatively new topic. Both studies (Scherak, Rieckmann 2020; Collazo-Expósito, Granados-Sánchez 2020) on ESD competences were published in 2020. According to their authors, education for sustainable development should represent an effort of university teachers to present various alternatives and possibilities of problem solving, not only try to lead the students to certain attitudes and perspectives. Ultimately, competences related to inclusive education, as well as research, key, personality, organisational and managerial, methodological, information, and communication competences were each part of one study.

We also want to draw attention to the significant predominance of studies using quantitative design and questionnaires. However, most of the analysed questionnaires were of original design, i.e. the authors rarely used standardised measurement tools. Four empirical studies used standardised questionnaires, while one study used its adjusted version. Its authors, Koshmaganbetova et al. (2020), pointed out there was a lack of standardised questionnaires dealing with competences, though the demand for this tool is clearly high. The analysed set of the studies used a total of 7 standardised questionnaires, 3 on digital competences, and 2 on competences for inclusive education. The analysed studies on social and research competences used one standardised questionnaire each. It is of interest therefore why studies focusing on pedagogical or professional competences, given their predominance, did not opt for any standardised questionnaire. Finally, the authors of several studies (Yakubov et al., 2020, Koshmaganbetova et al., 2020, Scherak and Rieckmann 2020) argue in their results the lack of defined assessment criteria for professional competence or teachers' competences, claiming that therefore it is not possible to unify teachers' competence profile and to standardise a sufficient number of tools. On the other hand, most of the original questionnaires used for the specific studies were structurally transparent, among other things indicating reliability test results, number of items in the questionnaire, and assessment scales. In total, our analysis identified 13 original questionnaires or self-assessment tools.

Focus groups, consisting of a minimum of 5 and maximum of 27 participants, were the second most frequently used tool in the selected empirical studies ( 5 studies). Two studies held focus groups immediately after questionnaire measurement for a large number of respondents. The aim was to enhance information and knowledge firstly on the level of digital and secondly pedagogical competences. One study used the focus group to assess a draft questionnaire on digital competences, while another study used this tool to collect suggestions of key competences from amongst its participants and subsequently to design a measurement tool. Finally, the study of ESD competences used the focus group to determine the effectiveness of the training.

It is worth mentioning the analysis of the selected 20 empirical studies revealed that only 9 of them focused on determining the level of competences, of which four examined digital, two pedagogical, one social, one research and one inclusive education competences. For these purposes, 5 studies used a standardised questionnaire and 4 studies used a self-designed questionnaire. The results show that all standardised questionnaires (7) identified in our study were used to determine 
the level of competence.

One of our study's aims was summarising the type of university teachers' competences defined through the 6 competence profiles we identified, of which 3 were generally structured and 3 focused specifically on digital, pedagogical. and personal competences. Comparing the competences that were part of these profiles and competences (13) that were the subject of the analysed studies' content, we can state that many competences essential for a teacher's job are not subject of research interest. Examples include motivational or publishing competences, defined by Blašková et al. (2014), and interpersonal, teamwork and innovative competences identified by Perez-Poch and López (2016). The competence model by Fakhrutdinova et al. (2020) is very specifically structured, including such competences as value-semantic, general cultural, educational and cognitive, and socio-labour competences - none of which were identified in our analysis of 35 studies.

Last but not least, the study by Pérez and Torelló (2012) consists of a draft design of two competence profiles, pedagogical and digital. The authors focused more on teachers' activities in the educational process. Attention should be turned, in our opinion, to competences or teachers' activities principally considering students' needs and interests, promoting an individual approach to education and students' autonomy, while encouraging teachers to constantly strive to improve teaching and to participate in a given institution's various professional networks.

\section{Conclusion}

Both theoretical knowledge and research dealing with university teachers' competences, not to mention the lack of standardised tools that can be used in this area, is limited. In general, competence assessment studies mostly focus on the competences required of university students or, conversely, of primary and secondary school teachers. In recent years, however, the quality of higher education has come to the fore, also due to globalisation processes or the growing importance and value of education. Such trends predict the need to take a closer look at the issues of quality and competence of higher education teachers.

\section{Acknowledgements}

The authors gratefully acknowledge the financial support of VEGA Agency at the Ministry of Education, Science, Research and Sport of the Slovak Republic and the Slovak Academy of Sciences under the VEGA project 1/0794/19 Professional Identity and Quality of Higher Education Teacher in Context of Andragogical Competency.

\section{References}

Abykanova, B., Tashkeyeva, G., Idrissova, S., Bilyalova, Z., Sadirbekova D. (2016). Professional Competence of a Teacher in Higher Educational Institution. International journal of environmental E science education. 11 (8), 2197-2206. doi: 10.12973/ijese.2016.560a.

Alqiawi, D. A., Ezzeldin, S. M. A. (2015). Suggested Model for Developing and Assessing Competence of Prospective Teachers in Faculties of Education. World Journal of Education, 5(6), 65-73. doi:10.5430/wje.v5n6p65.

Blašková, M., Blaško, R., Jankalová, M., Jankal, R. (2014). Key personality competences of university teacher: comparison of requirements defined by teachers and/versus defined by students. Procedia - Social and Behavioral Sciences 114, 466 - 475. doi: 10.1016/j.sbspro.2013.12.731.

Blašková, M., Blaško, R., Kucharčíková, A. (2014). Competences and Competence Model of University Teachers. Procedia - Social and Behavioral Sciences 159, 457 - 467. doi: 10.1016/j.sbspro.2014.12.407.

Blašková, M., Blaško, R., Matuska, E., Rosak-Szyrocka, J. (2015). Development of Key Competences of University Teachers and Managers. Procedia - Social and Behavioral Sciences 182, 187 - 196. doi: 10.1016/j.sbspro.2015.04.755. 
Collazo-Expósito, L. M., Granados-Sánchez, J. (2020). Implementation of SDGs in University Teaching: A Course for Professional Development of Teachers in Education for Sustainability for a Transformative Action. Sustainability 12(19), 8267. doi: 10.339o/su12198267.

Dias-Trindade, S., Moreira, J. A., Gomes Ferreira, A. (2020). Assessment of university teachers on their digital competences. QWERTY 15 (1), 50-69. doi: 10.30557/QWoooo25.

Dijk, E.E., Tartwijk, J., Schaaf, M.F., Kluijtmans, M. (2020). What makes an expert university teacher? A systematic review and synthesis of frameworks for teacher expertise in higher education. Educational Research Review, 31. doi:10.1016/j.edurev.2020.100365.

Dută, N., Rafailaa, E. (2014). Training the competences in Higher Education - a comparative study on the development of relational competencies of university teachers. Procedia - Social and Behavioral Sciences 128, 522 - 526. doi: 10.1016/j.sbspro.2014.03.199.

Ellerani, P., Mendoza, M. J. G. (2013). A participatory process to build and improve the competence profile of teachers using e-portfolio. A case study in an Higher Education Network. Procedia - Social and Behavioral Sciences, 83, 659 - 666. doi: 10.1016/j.sbspro.2013.06.125.

Fakhrutdinova, A. V., Ziganshina, M. R., Mendelson, V. A., Chumarova, L. G. (2020). Pedagogical Competence of the High School Teacher. Int. J. High. Educ. 9 (8), 84-89. doi:10.5430/ijhe.v9n8p84.

Fernández-Agüero, M., Chancay-Cedeño, C. (2019). Interculturality in the Language Class - Teachers' Intercultural Practices in Ecuador. RELC Journal, 5o(1), 164-178. doi:10.1177/oo33688218755847.

Gonzalez-Sanmamed, M., Munoz-Carril, P. C., Sangra, A. (2014). Level of Proficiency and Professional Development Needs in Peripheral Online Teaching Roles. The International Review of Research in Open and Distance Learning, 15(6), 162-187. doi:10.19173/irrodl.v15i6.1771.

Gridneva, S. V., Vasyakin, B. S., Ovsyanik, O. A., Pozharskay, E. L., Berezhnaja, M. S. (2017). Modern Health Improving Psychotechnologies of a Higher School Teacher's Personality. Eurasian Journal of Analytical Chemistry, 12(5b), 823-834. doi:10.12973/ejac.2017.00214a.

Ke, Z., Borakova, N., Valiullina, G. V. (2017). Peculiarities of Psychological Competence Formation of University Teachers in Inclusive Educational Environment. EURASIA Journal of Mathematics Science and Technology Education 13(8), 4701-4713. doi: 10.12973/eurasia.2017.00947a.

Koshmaganbetova, G. K., Kurmangaliyeva, S. S., Kashkinbayeva, A. R., Kurmangaliyev, K. B., Alekenova, N. U. (2020). Research Competencies of Medical University Teachers: Evaluation, Perception, and Perspective. Open Access Macedonian Journal of Medical Sciences, 8(E), 181-187. doi:10.3889/oamjms.2020. 3954.

Khushnaev, O. A., Rakhmatova, F. M. (2020). Scientific and methodical basis for evaluation of design competencies of future engineers. Jour. of Critical Reviews, 7(9), 274-276 doi:10.31838/jcr.07.09.6o.

Mattila, A. (2015). The future educator skills in the digitization era: Effects of Technological Development on Higher Education. 2015 Fifth International Conference on e-Learning, 212-215. doi:10.1109/ECONF.2015.18.

Merkt, M. (2017). The importance of academic teaching competence for the career development of university teachers: A comment from higher education pedagogy. Journal for Medical Education, 34(4). doi:10.3205/zmaoo1125.

Mirete, A. B., Maquilón, J. J., Mirete, L., Rodríguez, R. A. (2020). Digital Competence and University Teachers'Conceptions about Teaching. A Structural Causal Model. Sustainability, 12. doi:10.3390/su12124842.

Ochepovsky, A. V., Kulagina, J.A., Vaganova, O. I., Smirnova, Z. V., Lapshova, A.V., Kaznacheeva, S.N., Zhitnikova, N.E. (2009). Information Competence of a Teacher of Higher Education as an Important Component of Modern Educational Process. International Journal of Innovative Technology and Exploring Engineering, 8 (9). 2048-2053. doi:10.35940/ijitee.I8938.078919.

Okolie, U. C., Igwe, P. A., Nwajiuba, C. A et al (2020). Does PhD Qualification Improve Pedagogical Competence? A Study on Teaching and Training in Higher Education. Journal of Applied Research in Higher Education, 12 (5), 1233-1250. doi: 10.1108/JARHE-02-2019-0049.

Perez-Poch, A., López, D. (2016). Do differences exist between how Engineering and non-Engineering lecturers perceive the importance of teaching competences? Frontiers in Education (FIE) Conference. doi: 10.1109/FIE.2016.7757559.

Pérez, K. V., Torelló, O. M. (2012). The digital competence as a cross-cutting axis of higher education teachers' pedagogical competences in the european higher education area. Social and Behavioral Sciences 46, $1112-$ 1116. doi:10.1016/j.sbspro.2012.05.257.

Ruiz-Cabezas, A., Medina Domínguez, M. D. C., Navío, E. P., Rivilla, A. M. University teachers' training: the Digital Competence. Medios y Educación (58), 181-215. doi:10.12795/pixelbit.74676.

Semrádová, I., Hubáčková, Š. (2014). Responsibilities and Competences of A University Teacher. Procedia - Social and Behavioral Sciences 159, 437 - 441. doi: 10.1016/j.sbspro.2014.12.403. 
Sergeeva, M. G., Kodaneva L. N., Islamov A. E., Kornakova E. S., Serebrennikova A. V., Panko Iu. V., Avdeeva T. V. (2019). The development of teachers pedagogical competence in the conditions of professional educational organization. Humanities E Social Sciences Reviews 7(4), 827-832. doi:10.18510/hssr.2019.74109.

Scherak, L., Rieckmann, M. (2020). Developing ESD Competences in Higher Education Institutions-Staff Training at the University of Vechta. Sustainability, 12, 10336. doi:10.3390/su122410336.

Sjöberg, S., Lilja, P. (2019). University Teachers' Ambivalence about the Digital Transformation of Higher Education. Int. J. Learn. Teach. Educ. Res. 18 (13), 133-149. doi:10.26803/ijlter.18.13.7.

Solovova, N. V., Sukhankina, N. V. (2020). Comparative and Correlation Analysis of Experimental Work for Developing Organisational and Managerial Competences in University Teachers. Education and Self Development, 15(3), 97-108. doi: 10.26907/esd15.3.09.

Toleubekova, R. K., Sarzhanova, G. B., Georgyevna, S. M., Kazhabergenovich, S. D., Temirgalievich, B.O. (2016). The use of Information Technologies (IT) in the Formation, Development and Improvement of the Competence of Higher Education Teachers. Indian Journal of Science and Technology, 9(19), doi:10.17485/ijst/2016/v9i19/90073.

University of Stavanger (2020). Guidelines for appointment and promotion to teaching and research posts at The University of Stavanger. [Online] Available: https://www.uis.no/sites/default/files/2020-12/ Guidelines\%2ofor\%2oappointment\%2oand\%2opromotion\%202021.pdf

Velasco, L.C., Tójar, J.C. (2018). Competency-Based Evaluation in Higher Education-Design and Use of Competence Rubrics by University Educators. Int. Educ. Stud., 11 (2). doi:10.5539/ies.v11n2p118

Yakubov, K., Egamova, A., Yakubova, D. (2020). The recomendations for the further evaluation of professional competence of a university teacher. Journal of critical reviews, 7(5), 482-484. doi: 10.31838/jcr.07.05.103.

Zelenková, A., Hanesová, D. (2019). Intercultural competence of university teachers: a challenge of internationalization. Journal of Language and Cultural Education, 7(1). doi: 10.2478/jolace-2019-0oo1. 